\title{
Dakwah Strategies of Sharia Tourism: The Case of Gili Air, North Lombok
}

\author{
Lalu Ahmad Zaenuri \\ Universitas Islam Negeri Mataram \\ email: zaenuri.muslim@uinmataram.ac.id
}

\begin{abstract}
For the past few years, Lombok in particular and West Nusa Tenggara in general have not only been known as an island of thousand mosques, but also as a world tourist destination, particularly Shari'a compliance (halal) tourism. With such a new branding, respective stakeholders on the island should therefore make an effort to plan strategies for presenting the concept of halal tourism that serve and benefit both domestic and foreign tourists. Dakwah (Islamic propagation/preaching) can play an important role in strengthening local people's faith while also balancing between religiosity and tourism. This study looks into how the halal tourism 'brand' can be manifested in Gili Air, one of the famous small islands of tourist destination located in the northern part of Lombok. The study reveals that the dakwah strategies for shari'a tourism in Gili Air are carried out through twofold strategies, namely da'wah bi al-lisān and da'wah bi al-hāl. The first refers to a model where the activities of propagation revolve around preaching of Islamic tenets. The latter emphasizes actualization of Islamic doctrines into daily life.
\end{abstract}

Keywords: Strategies, $d a^{\prime} w a h$, halal toursm, sharia.

DOI: https://doi.org/10.20414/ujis.v22i2.327

\section{Introduction}

SINCE THE LAST FEW YEARS, Lombok, an island located east of Bali and west of Sumbawa in the province of West Nusa Tenggara, has increasingly become one major tourist destination. It now has a new brand. It is known not only as the island of thousand mosques but also the best halal tourism destination. With such a new branding, stakeholders in the island should therefore attempt to make strategies to promote tourism that serve and benefit both domestic and foreign tourists and to tackle common problems of 
tourism such as clean environment. ${ }^{1}$ Moreover, Lombok is mostly inhabited by Muslims who are in demand for playing a role in swaying people through conducive, safe, and Islamic-based values condition that correspond to the international brand awarded. Therefore, dakwah should spring as a locomotive in the socialization of Sharia or halal tourism and maintain balanced relationship with other aspects of tourism.

Dakwah is defined as a process of communicating or calling for divine teachings to human beings. Seen from the authorized view, carrying out the propagation peacefully is mandatory for each human believing in Allah, in compliance with each individual's capacity and ability. It has a broad coverage within the context of commanding the good and forbidding the evil (amr bi al-ma' rüfwa nahy 'an al-munkar). Problems existing in the society should be firstly examined before one can carry out and decide the method of dakwah because that will brings about positive changes in the society. For that reason, it is extremely pivotal for $d \bar{a}^{\prime} \bar{\imath}$ or muballigh (preachers) to figure out and equip them selves with any knowledge and skill pertinent to the society and its problems. ${ }^{2}$ Dakwah requires not only mastering the content or substance of Islamic precepts but also acquiring communicative skill and good performance. $^{3}$

Whilst global life is happening nowadays, tourism has been an important part of human. Consequently, it is not a monopoly of urban or rich people, but it is now everyone's concern, including Muslims. In this respect, the presence of foreign tourists who come

${ }^{1}$ Mark Hampton and Joanna M Hampton, "Is the Beach Party Over? Tourism and the Environment in Small Islands: A Case Study of Gili Trawangan, Lombok, Indonesia," in Tourism in Southeast Asia: Challenges and New Directions, ed. MichaelHitchcock, Victor T. King, and Michael Parnwell (London: Routledge, 2008), 254-269.

2 Asmuni Sukir, Dasar-dasar Strategi Dakwah Islam (Surabaya: Al-Ikhlas, 1983), 65.

3 Syahida Yasya Moeniri, "Like Islam Project, Strategi Dakwah Masa Kini," Dirosat: Journal of Islamic Studies 2, no. 1 (November 19, 2017):59-74-74, accessed August 30, 2018, http://ejournal.idia.ac.id/index.php/dirosat/a rticle/view/66. See also A. Syarifuddin, “Dakwah Komunikatif: Kenapa Tidak?," Wardah: Jurnal Dakwah dan Kemasyarakatan 16, no. 1 (2015): 53-62, accessed June 30, 2018, http://jurnal.radenfatah.ac.id/index.php/warda/article/view/358. 
with a variety of cultures and expressions as well as different lifestyle will directly or indirectly benefit or influence Muslim community of the host tourism destination. Or, that may stir up controversies due to different cultural backgrounds between visitors and local hosts of tourist destination.

With all the risks and consequences of the existence of tourism, it is inevitable for people to come across its impact, particularly when seen from the changes in people's behavior. As the previous study by Fallon has showed, Lombok faced formidable challenges to sustainable tourism, ${ }^{4}$ although another study pointed out the implication of shari'a tourism to the people's income and prosperity. ${ }^{5}$ And now Lombok receives a new brand as halal tourism, which spurs controversies as how Islam and tourism will encounter. In this case, dakwah plays an important role in balancing the Islamic propagation and the demand of tourism. This study thus aims to examine how the halal tourism 'brand' could be manifested in Gili Air, one of the noted small islands in the northern part of the island. It analyzes the intersection of Islamic propagation and tourism in dealing with sharia tourism project on Gili Air, north Lombok.

\section{The Definition of Sharia Tourism}

Generally, tourism in Pendit's view is one or more's temporal trips toward different places beyond their home boundary. The impetus for taking the trip is not only due to such various interests, such as economic, social, cultural, political, religious, and health interests, but also other kinds of interests, such as curiosity to get more experience or study. 6 Guyer-Freuler, as cited by Pendit, points out that tourism is a phenomenon on the need of health and conditional change, conscious evaluation and growing

\footnotetext{
${ }^{4}$ Fleur Edith Fallon, “Tourism Interrupted: The Challenge of Sustainability for Lombok Island 1987-2001" (Ph.D. Thesis, University of New England, 2002).

${ }_{5}$ Fitratun Ramadhany and Ahmad Ajib Ridlwan, "Implikasi Pariwisata Syariah Terhadap Peningkatan Pendapatan Dan Kesejahteraan Masyarakat," Muslim Heritage 3, no. 1 (June 2, 2018): 157-176, accessed October 30, 2018, http://jurnal.stainponorogo.ac.id/index.php/muslimheritage/article/view/1303.

6 Nyoman S. Pendit, Ilmu Pariwisata: Sebuah Pengantar Perdana (Jakarta: Pradya Paramitha, 1999), 20.
} 
love to natural beauty, and particularly the increase of interaction among people across different nationalities and social classes as a result of the advance of commerce, industry, trading, as well as the improvement of transportations. ${ }^{7}$

Meanwhile, Sharia tourism by definition is an activity supported by countless facilities and services offered by the society, entrepreneurs, and local government which meet Islamic Sharia. These available facilities and services are not different from other general facilities yet do not contradict the Islamic values. Therefore, Muslim society can freely relish the available facilities. The other similar term is "spiritual tourism". Nashuddin argues that Lombok offers great potencies of spiritual tourism since it has a number of sites where people may visit to enhance their spiritual experience, but it also faces impeding challenges such as lack of management on safety and cleanness. ${ }^{8}$ This present study is a continuation of such pervious study but focuses on the strategy of dakwah in promoting halal tourism in Gili Air.

Sharia tourism has been introduced since 2000 on the basis of the consensus of Islamic Countries Organization conference. Sharia tourism is tourism appealing according to Muslim tourists' lifestyles during vacations. Besides, it is a flexible, rational, simple and balanced. This concept of tourism aims to encourage tourists to reach happiness and blessings from Allah.

Apart from the Sharia tourism term, the term "halal tourism" is also widely used. During the launch of Sharia tourism which is in coincidence with Indonesian Halal Expo in 2013 and Global Halal Forum held on December $30^{\text {th }}$ November in Semeru Room, Floor 6, Commerce Center building, JIExpo, Kemayoran, Jakarta, Wednesday (30/10/2013), the President of Islamic Nutrition Council of America, Muhammad Munir Caudry, remarked "Halal tourism is a new tourism concept. It is not a pilgrimage such as Umra or Hajj. Halal tourism is tourism that serves vacation by regulating its style in accordance with the need and request of

\footnotetext{
${ }^{7}$ Ibid., 38.

8 Nashuddin, "The Management of Muslim Spiritual Tourism in Lombok, Indonesia: Opportunities and Challenges," Journal of Indonesian Islam 10, no. 2 (December 1, 2016): 213-236, accessed July 29, 2018, http://jiis.uinsby.ac.id/index.php/JIIs/article/view/345.
} 
Muslim travelers". In this respect, any hotels that hold Sharia principles must not serve alcoholic beverages and have separate swimming pools and facilities for men and women.

Based on the definitions above, Sharia concepts that do not violate or contradict the values and ethics of Sharia are linked to the halal concepts in Islam. Halal refers to the allowed, whereas haram means the forbidden. Halal concept can be seen from two perspectives: religious and industrial perspectives. The former refers to the regulation on types of food consumable for Muslim consumers. Meanwhile, from the industrial perspective, the halal concept can be understood as a potential business chance for food manufacturers. For the manufacturers whose targets are mostly Muslims, it is necessary to have halal guarantee of the products, which will enhance its intangible value. For instance, food product with halal label is more interesting for Muslim consumers.

\section{An Overview of Gili Air}

\section{Administration and Population}

Administratively, Gili Indah village is under the region of Pemenang sub district, north Lombok. It was established based on the Decree issued by the Governor Number 20/1995, dated January 23rd. The village itself consists of three gilis (small islands), namely Gili Air, Gili Meno and Gili Trawangan. In its administration, each Gili is regarded as a sub village and each is led by a head. Therefore, the village consists of three sub villages: Gili Air, Gili Meno, and Gili Trawangan.

Public institutions in Gili Indah comprise of governmental organization such as village, sub village, and village council while non-governmental organizations involve Front Pemuda Satgas Gili (FPSG), Gili Eco Trust, Gili Indah Lestari Foundation, and other NGOs. In addition, there has been established an island security which is responsible for the security and safety in Gili Trawangan.

The organizational structure in Gili Indah has been remarkable and complete because it constituted by experts according to their area of expertise. Besides, village institutions in Gili Indah are complemented by the Board of Representatives whose duty is to monitor village performance. 
The spread of people and the composition of the population in Gili Indah is uneven. Most people live in Gili Air, while least people live in Gili Meno. Based on the data from the village office, the number of citizens by October 2015 was 3.618.

Overall, the number of Gili Indah citizens reached 1.835 of male and 1.783 of female inhabitants. Additionally, the number of family head was 925 . It is worth noting that foreign people also live in these three Gilis. There were 12 foreigners in Gili Air, 2 in Gili Meno, and 11 in Gili Trawangan.

Most of the people in the village deal with tourism industries, such as transportations, homestays, cafés, coffee shops, and other tourism services. Some people also work in agriculture, particularly coconut farming, yet only few of them earn living as fishermen.

\section{The Education State of Affairs}

In Gili Indah, there have been several educational levels involving Kindergarten, Primary school, Junior as well as Senior High School. Kindergarten and primary schools are located in each Gili. Nonetheless, Junior high school can only be found in Gili Air and Gili Trawangan. Meanwhile, a junior high school presents in Gili Trawangan and an Islamic junior high school is in Gili Air. ${ }^{9}$

In my interview with Ki Agus, one of the youth figures in Gili Air as well as the founder of an Islamic junior high school, he said:

"In the beginning, we the young generation of Gili Air people who once undertookstudy out of Gili gathered and discussed the idea of founding an Islamic school since in Gili Air itself, there was no secondary school. Alhamdulillah, the idea received considerable responses from the senior figures in Gili Air". ${ }^{10}$

Meanwhile, for the senior high school level, there is a vocational high school located in Gili Trawangan. The findings of my observation and interviews with informants suggest that the majority of youths of Gili Trawangan went to Islamic Boarding School in Lombok and even reached further place of Islamic schools such as in Java.

${ }_{9}^{9}$ Observation at Gili Air, 24 August 2017.

${ }^{10}$ Interview with Ki Agus, 24 August 2017. 
H. Damsiah said nearly most of the teenagers in Gili went to Islamic school in Tanjung, such as al-Istiqamah Islamic Boarding School in Kapu, Jenggala, Tanjung sub district. There are also some of them who study at Nurul Bayan in Bayan, North Lombok, at Nurul Hakim in West Lombok, and even some study at Ibrahimy Islamic school in Sukorejo, East Java. He further maintained that the people were eager to send their children to pesantren (Islamic boarding school) due to parents' awareness and realities they are encountering. Living in tourism area such as Gili Air brings about great challenges, as this figure asserted. Therefore, acquiring deep science and knowledge of Islam is necessary and studying Islam at qualified and reputable Islamic school is considered the best choice for the youth education. ${ }^{11}$

In line with my interview with Nyi Ayu Nuraini, one of the alumni of Al-Istiqamah Boarding School, Kapu, Tanjung, she said:

"We thank God for being once schooled by our parents at Isla mic boarding school. The life challenges we have are truly hefty. We have to be able to live in the middle of tourism area realities which coexist with numerous problems, malicious deeds, drugs, discotheque, and the like. However, the knowledge we gained from Islamic Boarding School still remains to help us defend ourselves despite its huge complications". ${ }^{12}$

This perspective reveals the ways in which a young female generation face the problems of living in the tourist destination and the solution that she was taking. To her, going to an Islamic school serves as a bulwark against all moral corrupt implicated for being a place where various people from different religious, cultural, and economical backgrounds from across the globe encounter in Gili.

\section{Religions and Customs}

Most Gili Indah people embrace Islam as their religion (99\%), while the rest are Hindus and Christians. Places of worship include mosques and mushalla (prayer rooms). There are 4 mosques and mushalla at Gili Air, 2 at Gili Meno and 4 at Gili Trawangan. Hindus and Christians may have their religious observance outside of the island of Gili. From my observation in Gili Air, at

${ }^{11}$ Interview with H. Damsiah, 24 August 2017.

12 Interview with Nyi Ayu Nuraini, 24 August 2017. 
present, there is a construction process of a huge and grand mosque. Seen from its interior, the mosque is beautiful since it uses ceramics with well-crafted and neat Arabic calligraphies. ${ }^{13}$ These religious places and other buildings have been affected by series of earthquake that rocked Lombok and Nusa Tenggara Region in general several months of the middle of 2018.

In the interview with a prominent figure in Gili Air, $\mathrm{H}$. Damsiah said that the construction of the mosque involves all parties from both commoners and entrepreneurs in Gili Air. He said that in Gili Air there are lots of entrepreneurs in tourism accommodations, restaurants, and other businesses. All of them participated in the mosque construction. Moreover, the function of the mosques for Gili Air people is truly significant particularly for spiritual empowerment of human beings in the middle of the development of tourism sectors. ${ }^{14}$ This suggests that dakwah and entertainment intermingled and aligned one another to pave the way of a mutual close relationship.

In terms of ethnicity, the majority of the people in Gili Indah (75\%) come from South Sulawesi (Bugis), some of them are Sasak, Balinese, Javanese, and Madurese. The dominance of the Bugis can be understood with regard to the vacancies of these three islands in the past. The Bugis were the pioneers for inhabiting uninhabited islands in the past. Therefore, it is no wonder if the prominent figures including the heads of villages are Bugis descendants. The same goes here for the customs, which are mostly influenced by South Sulawesi (Bugis) culture.

Nasir, who is also the prominent figure of Gili Air people, reveals that nearly all native people of Gili Air are from Bugis, Makassarese. That is not surprising that all cultural expressions, languages, and customs reflect the Bugis tribe. Gili Air people tend to use more Bugis/Makassarese language in their daily activities than to that of Sasak language or others, including the customary expressions such as clothing manner in wedding party or other ceremonies. ${ }^{15}$

\footnotetext{
${ }^{13}$ Observation, 23 August 2017.

${ }^{14}$ Interview with H. Damsiah, public figure from Gili Air, 24 August 2017.

${ }^{15}$ Interview with Bapak Nasir, 24 August 2017.
} 


\section{Tourism-Sustaining Tools and Infrastructure}

The development of tourism facilities is one of the development programs, which plays important roles in sustaining tourist industries. Without the support of the infrastructure development, the planned programs will not reach its optimal goals.

To support the tourist activities in Gili Air, the development and provision of tourism-sustaining infrastructure and facilities has grown rapidly. This can be seen from the construction of homestays, hotels, restaurants, café, and other tourism facilities.

Specifically, Gili Air, where this research was mostly based on, has the adequate number of tools and infrastructure of Sharia tourism. Above all, Gili Air people can be said to be extremely prepared for the Sharia tourism and halal food destination. This is consistent with what is conveyed by Rukding, one of the heads of Young Entrepreneurs Association (HPM) who in an interview said "Gili Air in general is well prepared and enthusiastic with the programs of NTB government, who supports the new branding of "Sharia tourism". One of the numerous factors that make the Gili the choice for Sharia tourism is the religion of its People since almost $99 \%$ of them are Muslims. In addition, there is a cultural factor which is strongly held and the people carry out the cultural norms, particularly Bugis Tribe Culture. ${ }^{16}$

Similar account was also conveyed by an entrepreneur in tourism, Raden Sukarto. He said:

"Upon the issuance of the provision of government program on sharia tourism and halal food destination, I alre ady put it into practice. I am not too bothered by the guests, because for me what is important is to become kind, friendly, honest, and smart. They must choose us. Alhamdulillah, until now the guests have never been absent although I am "extreme" in welcoming guests. For instance, we a ring suit should be polite, I do not supply alcoholic beverages, or even I play cassettes on re ligion like the Qur'anic recitation and Isla mic songs. To date, my guests have never complained, even they inquire further on Islam. This is how I support sharia tourism. ${ }^{17}$

16 Interview with Rukding, Head of Association of Gili Indah Youth Enterpreneur Association, 28 August 2017.

${ }^{17}$ Interview with Raden Sukarto at The Radenz Home Stay, North Lombok, 24 Agustus 2017. 
For the informant like Raden Sukarto, tourist and halal tourism should not be seen mutually excluding. Rather, they can exist side by side. Halal tourism was not understood as impediment to the foreigners who want to enjoy Gili. What the informant emphasized was on how he welcomed his guests. Playing the Quranic recitation or song does not seem to become bothersome for the tourists. If the halal tourism is perceived like this, he asserted, there would be no conflict between tourism, halal tourism and dakwah activities.

\section{Strategies for Sharia Tourism in Gili Air}

In general, strategy refers to guidance to take action to achieve a set of goals. ${ }^{18}$ Strategy means methods, tactics, or maneuver used during Islamic preaching activities. ${ }^{19}$ Strategy is a manual for propagation consciously devised and carefully planned to achieve its goals. Islamic mission is equipped with sustaining tools and strategy so it will work out. Different site of propagation target calls for a different strategy. In other words, strategy of propagation is contingent upon whom the mission will be addressed, where it will be delivered and what method will be best employed.

By and large, strategies for Sharia tourism in Gili Air can be categorized into two, namely da'wa bi al-lisān and da'wa bi al-hạl.

\section{Da'wa bi al-lisān}

$D a^{\prime} w a$ bi al-lisān is a preaching activity carried out through lecture, sermon, or even through storytelling. In the Qur'an, Allah mentions that this sort of dakwah strategy is the best man's deed, as He said:

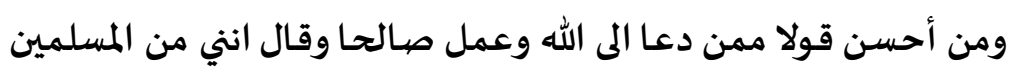

Who is better in speech than one who calls [men] to Allah, works righteousness, and says, "I am of those who bow in Islam"? (Q. S. Fuṣșilat, 33).

18 Syaiful Bahri Djamarah, Strategi Belajar Mengajar (Jakarta: Kencana, 2000), 5.

${ }_{19}$ Sukir, Dasar-dasar Strategi Dakwah Islam, 29. 
In this verse, it is mentioned that one of the indicators for a good person is calling and inviting people to God through his speech. Inviting or summoning humans to God's path to reach happiness of world and hereafter can be carried out with the good speech and language of dakwah.

In the context of Sharia tourism in Gili Air, da'wa bi al-lisān is carried out by focusing on the building of mental and spiritual religiosity. This kind of dakwah is mostly centered at mosques since the existence of mosques is viewed to be strategic for the activities of gathering numerous people.

The dakwah performed in the Gili Air mosques cover a number of activities. First, it includes public Islamic lecture, which is carried out once a week on Wednesday evening after congregated Maghrib prayer until the start of Isha time. Usually, the weekly Islamic lecture like this is delivered by tuan guru or religious figures from outside of Gili Air. ${ }^{20}$ The existence of a huge, beautiful, and prosperous mosque has been an appeal in in the small island. Commonly, it is so difficult to find place for praying or even a big mosque. However, in Gili Air, a mosque is located in the middle of people settlement and is reachable by tourists. This has become the magnet to the tourists and has been the framework brand of creating Sharia tourism.

For that reason, if we look at the role of mosques in Gili Air, it can be said to be very central to any kinds of religious activities, such as Islamic lecture, the celebration of Islamic fests and useful channel of communication, especially of those involving the community. Even, the atmosphere in the Gili does not seem to be like tourism area since the spirit of living the mosque by the people is highly glaring.

In relation to the mosque activities which will support the application of Sharia tourism, a lot of things have been carried out. First, the obligatory prayer is attended by no fewer than two lines of congregational member. In Islam, it is not only commanded to

${ }^{20}$ On excellent studies of Muslim religious figures (tuan guru) on Lombok, see Fahrurrozi, “Tuan Guru and SocialChange in Lombok, Indonesia," Indonesia and the Malay World 46, no. 135 (May 4, 2018): 117-134, https://doi.org/10.1080/13639811.2018.1452487. 
build physicality, but also to live the mosque with activities, such as congregational obligatory prayer and other activities. Second, routine activities are carried out in mosques such as weekly Islamic lecture. In the lecture, speakers from religious figures or tuan guru from outside Gili Air are invited to deliver Islamic lecture (pengajian) on actual and relevant religious issues. Third, discussion program after obligatory prayers is undertaken by one person in the elder group. The routine of this kind of lecture is usually performed by the community gathering in the lecture group called "Jamā'ah Tabligh". In the contemporary discourse, this group is known as Muslim travellers. They are keen to spread Islam through dakwah activities. Each member of it is required to go out (khurūj) of their home to perform Islamic propagation. ${ }^{21}$

Fourth, weekly prayer and sermon is held every Friday, which is mandatory prayer to adult Muslims. Besides, we know that Friday prayer sermon has a very strategic position for Muslims, particularly in conveying spiritual messages publicly and weekly. This weekly sermon is very important and strategic Islamic ritual and gathering because it is attended by all adult male members. Muslim preachers have chance to disseminate Islamic thoughts and dominate the discourse on it since there is no dialogue after the sermon. In other words, preachers are the sole active player in making Islamic discourse while the congregational members are passive listeners.

Friday prayer and its sermon must be held in every Muslim community. This sermon provide powerful message to its audience where preachers can arrange the substance of their sermon as they wish. It is therefore important to single out the most appropriate preacher so the message will not cause any problem or tension.

The forum is attended by communities who are psychologically prepared to receive advice since they come with praying intention toward Allah. Therefore, they have solid spiritual state. In other words, the forum is in ready condition to

${ }^{21}$ See Muhammad Khalid Masud, ed., Travellers in Faith: Studies of the Tablīghī Jamā'at as a Transnational Islamic Movement for Faith Renewal (Leiden: E. J. Brill, 2000). 
direct the audient to obey Allah and to receive advice which leads toward pitifulness and obedience to Him. Therefore, the preacher can always implant the message of piety and spirituality into their audience in all aspects of their life whether in faith, worship, morals and the others.

The forum has a short duration (10 minutes or at maximum 15-20 minutes), without question and answer session, and cannot be interrupted. This means that the forum is ready to listen to anything said by the preacher in his advice. Therefore, the preacher should really effectively use his words so that it goes deep into the deepest heart. The preacher should avoid unnecessary words and repetitions, except for the emphasis and strengthening of the meaning. The congregation should not be bored, sleepy, and fall asleep. The words should be brief, solid, clear, and be delivered with loud as well as clear voice with serious tone, so that they can be grasped seriously with full attention.

Another method of bi al-lisān strategy is through the celebration of Islamic holidays. In Gili Air, as in Lombok in general, one of the most celebrated days is the birthday of the Prophet Muhammad. It is annual festival. The Islamic New Year (Tahun Baru Hijriah) and the Ascending of the Prophet to the Sky (Isra Mi'raj) constitute two other celebration, in addition to two biggest feast of 'I $\bar{l} d$ al-Fițr (End of Fasting Month) and 'I $\bar{l} d a l$-'A $d h \bar{a}$ (the Day of Hajj)

\section{Da'wa bi al-Hāl}

$D a^{\prime} w a$ bi al-hāl means propagate Islamic teaching through an actual example of practice and experience. This type of Islamic propagation encompasses a wide variety of spreading Islam by means of actual or real action. ${ }^{22}$ Yunan Yusuf, as cited by Munzier Suparta, elaborates that this propagation refers to any activities through real actions. Since it is a real action, it tends to emphasize actions, activities, and attitudes that reflect the teachings of

${ }_{22}$ Mundzier Suparta, Metode Dakwah: Sebuah Pengantar Kajian (Jakarta: Rahmat Semesta, n.d.), 220. 
Islamic. Thus, it is oriented more to social development. ${ }^{23}$ Similarly, Basrah Lubis expounds the definition of it as Islamic preaching through actions that may start from the way of dressing, saying, behaving, and up to working, such as founding an orphanage, giving charity to the poor, building schools, renovating broken public facilities and the like. ${ }^{24}$

Some types of this propagation carried out in Gili Air in an effort of realizing Sharia tourism include several programs. First, it relates to the construction of a glorious and large mosque. The construction of the mosque is originally community-funded by different elements of society, whether in public or hospitality and restaurant entrepreneurs which exist in Gili Air. The first goal of the mosque serves purposes as a brand for realizing Sharia tourism. Consequently, the Gili has specific characteristics in comparison with other tourism areas.

Second, another manifestation of actual Islamic propagation in the Island is concerned with the construction of religious schools, such as Raudhatul Athfal (at a level of Kindergarten) and Madrasah Tsanawiyah (at a level of junior high school) as places for educating future virtuous generations. In early 2000, there had not been any religious school in Gili Air due to the limitation of resources. However, after the rise of Islamic boarding school alumni in this small island, the initiation to establish a religion-based educational foundation emerged. The construction of the madrasah or religionbased school does not only aim to provide chance for the kids to continue their education to a higher level, but also to give chance to the parents to get involved in the development of their kids beyond the school. The main goal of the religion-based school is as the shield in developing children's characters in the tourism area and as a tool in strengthening Sharia tourism brand.

This model of dakwah concerns the establishment of young entrepreneur association in Gili Air, abbreviated as HPM-Gili Air. This association is used as the forum of good relationship and communication medium amongst young entrepreneurs, including hotels, restaurants, or other businesses. This union is expected to

${ }^{23}$ Ibid., 221.

${ }_{24}$ Basrah Lubis, Pengantar Ilmu Dakwah (Jakarta: Tursina, 1993), 54. 
play a role in providing policies pertinent to Sharia tourism, such as halal food, qibla direction in each hotel or restaurant, holidays for Muslim workers, rights to perform Friday prayers or fest and other policies are orientated to collective goodness.

The other method of this propagation is the establishment of awik-awik or local rules related to dressing ethics in Gili Air for the tourists. The head of village and Gili Air have made rules that the wearing of mini clothing for anyone is only permitted in seashore when bathing, relaxing, or sunbathing. Nonetheless, in the settlement area both foreign and local tourists should adjust to the surrounding peoples' traditions or customs or at least should cover themselves with longer apparel. All this is intended to present Gili Air brand as Sharia tourism destination.

All explanations above are the manifestations of $d a^{\prime}$ wa bi al-hāl as strategy to realize Sharia tourism in the Gili. Therefore, we can draw a conclusion that this type of dakwah is an attempt to direct people to God's path by means of real actions leading to the development and changes of society, such as the development of public economy, education, socio-culture for humans' preference in the world and hereafter. In the development of economy, for instance, the objects of the should obtain the empowerment to carry out the attempts of economic activities, improving quality performance as well as productivity, and optimizing public economic resources. Therefore, they can be free of economic problems and poverty.

Similar things go on the field of education. The attempts to improve the quality of education through the mastery of science and technology, provision of adequate tools and facilities. Hence, the education can yield human resources who can compete with other educational institutions. In the field of social and culture, the tourism should be able to respond to the social drawbacks within the society, such as poverty, lavish lifestyle influenced by outsiders' culture as a consequence of modernization flows. Here, dakwah appears as a solution for the complexity of public problems. 


\section{Conclusions}

Although dakwah in a general meaning refers to the dissemination of Islam, it may take different form and strategy. In Lombok, especially North Lombok, dakwah calls for a wise strategy both in terms of method and substance. This study shows that strategies for Sharia tourism in Gili Air can be mainly carried out through two forms of strategy: $d a^{\prime} w a$ bi al-lisān and bi al-hāl. The former is carried out through a variety of ways that focuses on public sermon, Islamic lecture, celebration of Islamic holidays and routine Islamic lesson at mosques.

Different from but still related to the first model, the second strategy of dakwah stresses on the actual implementation of Islamic values. It is an act of propagating Islam through lived-experienced, actions, attitudes and behaviors to promote public welfare, as one objective of shari'a. In Gili Air, the promotion of the second strategy endorse the realization of halal tourism through various programs, ranging from building Islamic school, establishing glorious mosques, and setting up public role on piety and dress code. Because the dakwah is located at the center of tourist areas, the strategy that it adopts is adaptive without losing its branding od halal tourism.

\section{References}

Djamarah, Syaiful Bahri. Strategi Belajar Mengajar. Jakarta: Kencana, 2000.

Fahrurrozi. "Tuan Guru and Social Change in Lombok, Indonesia." Indonesia and the Malay World 46, no. 135 (May 4, 2018): 117-134. https://doi.org/10.1080/13639811.2018.1452487. Fallon, Fleur Edith. "Tourism Interrupted: The Challenge of Sustainability for Lombok Island 1987-2001." Ph.D. Thesis, University of New England, 2002.

Hampton, Mark, and Joanna M Hampton. "Is the Beach Party Over? Tourism and the Environment in Small Islands: A Case Study of Gili Trawangan, Lombok, Indonesia." In Tourism in Southeast Asia: Challenges and New Directions, edited by Michael Hitchcock, Victor T. King, and Michael Parnwell, 254-269. London: Routledge, 2008. 
Lubis, Basrah. Pengantar Ilmu Dakwah. Jakarta: Tursina, 1993.

Masud, Muhammad Khalid, ed. Travellers in Faith: Studies of the

Tablighì Jamā'at as a Transnational Islamic Movement for Faith

Renewal. Leiden: E. J. Brill, 2000.

Moeniri, Syahida Yasya. "Like Islam Project, Strategi Dakwah

Masa Kini." Dirosat: Journal of Islamic Studies 2, no. 1 (November 19, 2017): 59-74-74. Accessed August 30, 2018. http://ejournal.idia.ac.id/index.php/dirosat/article/view/66.

Nashuddin. "The Management of Muslim Spiritual Tourism in Lombok, Indonesia: Opportunities and Challenges." Journal of Indonesian Islam 10, no. 2 (December 1, 2016): 213-236. Accessed July 29 , 2018.

http://jiis.uinsby.ac.id/index.php/JIIs/article/view/345.

Pendit, Nyoman S. Ilmu Pariwisata: Sebuah Pengantar Perdana. Jakarta: Pradya Paramitha, 1999.

Ramadhany, Fitratun, and Ahmad Ajib Ridlwan. "Implikasi Pariwisata Syariah Terhadap Peningkatan Pendapatan Dan Kesejahteraan Masyarakat." Muslim Heritage 3, no. 1 (June 2, 2018): 157-176. Accessed October 30, 2018. http://jurnal.stainponorogo.ac.id/index.php/muslimheritage/ar ticle/view/1303.

Sukir, Asmuni. Dasar-dasar Strategi Dakwah Islam. Surabaya: AlIkhlas, 1983.

Suparta, Mundzier. Metode Dakwah: sebuah Pengantar Kajian. Jakarta: Rahmat Semesta, n.d.

Syarifuddin, A. "Dakwah Komunikatif: Kenapa Tidak?" Wardah : Jurnal Dakwah dan Kemasyarakatan 16, no. 1 (2015): 53-62. Accessed June 30, 2018. http://jurnal.radenfatah.ac.id/index.php/warda/article/view/35 8.

\section{Interview}

Interview with Bapak Nasir, 24 August 2017.

Interview with H. Damsiah, 24 August 2017.

Interview with H. Damsiah, public figure from Gili Air, 24 August 2017.

Interview with Ki Agus, 24 August 2017.

Interview with Nyi Ayu Nuraini, 24 August 2017. 
Interview with Raden Sukarto at The Radenz Home Stay, North Lombok, 24 Agustus 2017.

Interview with Rukding, Head of Association of Gili Indah Youth Enterpreneur Association, 28 August 2017. 